\title{
Current knowledge on the environmental fate, potential impact, and management of growth-promoting steroids used in the US beef cattle industry
}

S. Biswas, C.A. Shapiro, W.L. Kranz, T.L. Mader, D.P. Shelton, D.D. Snow, S.L. Bartelt-Hunt, D.D. Tarkalson, S.J. van Donk, T.C. Zhang, and S. Ensley

The beef cattle industry in the United States has been using a variety of growth-promoting steroids and steroidlike compounds (GPSCs) to improve cattle growth rates, feed efficiency, and lean muscle mass since 1954 (Raun and Preston 1997). Almost $96 \%$ of cattle placed in feedlots receive one or more GPSC treatments (USDA 2000). Although there are a number of natural steroids used as GPSCs, synthetic steroids are often more potent and biologically active than their natural analogs (Preston 1999). After administration, a portion of these natural or synthetic steroids and their metabolites are excreted into the environment either in animal feces or urine. Irrespective of GPSC treatment, animals also excrete natural endogenous steroids that also occur in feces and urine. In the United States, for example, an estimated 49,279 , and $4.9 \mathrm{Mg}$ $(54,307$, and $5.4 \mathrm{tn})$ of natural estrogens, progestagens, and androgens, respectively, are excreted annually by feedlot animals, and almost $90 \%$ of estrogens and progestagens and $40 \%$ of androgens are from cattle (Lange et al. 2002). Presumably in combination with endogenous compounds, synthetic steroids, such as trenbolone acetate and melengestrol acetate, may be metabolized and released into the environment only through cattle manure (liquid or solid). Natural and synthetic steroids have been detected at varying concentrations in manure, lagoon effluent, soil profiles, and in surface and groundwater (Schiffer et al. 2001; Hutchins et al. 2007; Arnon et al. 2008; Kolpin et al. 2002; Peterson et al. 2000). Several researchers have suggested possible adverse impacts of steroids in sur- face and groundwater including endocrine disrupting effects on aquatic life, animals, and possibly humans (Renner 2002; Raloff 2002; Falconer et al. 2006). Therefore, the main concern among the scientific community is whether the detected concentrations are great enough to affect aquatic and terrestrial life. If these compounds occur at relevant concentrations, also of concern are the controls that would be warranted to prevent their transport from animal production facilities or the associated lands treated with manure to surface or groundwater.

The economic benefits and increases in production efficiency gained by using GPSCs are significant. The use of GPSCs improves grain conversion to meat. Without the use of GPSCs, more feed is required to produce the same weight of beef, and the produced beef takes longer to achieve market weight. For producers, the cost savings from improved feed efficiency averages about US $\$ 40$ per animal compared to untreated animals (Raloff 2002). From the consumer's point of view, GPSC use is reflected in the reduced price of all beef products in the retail market. Additionally, use of GPSCs may benefit the environment by reducing nutrient loss and greenhouse gas emissions.

In addition to the livestock-associated GPSCs, humans use significant quantities of steroids and other pharmaceuticals in birth control and menopausal therapy that are subsequently discharged into surface water. Wastewater treatment plants, septic systems, rangeland grazing, aquaculture, and paper and pulp industries are common sources of natural and other synthetic steroids discharged into the environment (Swartz et al. 2006; Kolodziej and Sedlak 2007; Kolodziej et al. 2004; Jenkins et al. 2003; Young and Borch 2009). Thus, life cycle analysis of GPSCs used by the US beef cattle industry can and should be conducted to more accurately assess the benefits and environmental costs. Meanwhile, the major focus needs to be directed toward site-specific best management practices (BMPs) to reduce the adverse impacts on environment.

Because of the importance of this issue and the fact that the science of the fate, transport, and impacts of GPSCs are still being investigated, it is appropriate to summarize what is known and identify where there are critical knowledge gaps. It is in the public's interest to develop a policy to protect the environment. This paper focuses on the major scientific findings and issues related to the use of steroids by the cattle industry, their environmental impacts, and potential management to protect the environment.

Common Growth-Promoting Steroids Used by the Beef Cattle Industry and their Effects on Cattle Performance

The first synthetic growth promotant approved for beef cattle production was diethylstilbestrol in 1954. It was banned in 1979 for use in beef cattle after being identified as a carcinogen (Raun and Preston 1997). Since then, the US Food and Drug Administration (FDA) has approved 3 single

Sagor Biswas is a former graduate student, William L. Kranz is an associate professor, and David $\mathbf{P}$. Shelton is a professor in the Department of Biological Systems Engineering, University of Nebraska-Lincoln, Concord, Nebraska. Charles. A. Shapiro is a professor in the Department of Agronomy and Horticulture, University of Nebraska-Lincoln, Concord, Nebraska. Terry L. Mader is a professor emeritus in the Department of Animal Science, University of Nebraska-Lincoln, Concord, Nebraska. Daniel D. Snow is a research associate professor and director of Water Sciences Lab, University of Nebraska-Lincoln, Lincoln, Nebraska. Shannon L. Bartelt-Hunt is an assistant professor in the Department of Civil Engineering, University of Nebraska-Lincoln, Omaha, Nebraska. David D. Tarkalson is a research soil scientist in USDA Agricultural Research Service, Kimberly, Idaho. Simon J. van Donk is an assistant professor in the Department of Biological Systems Engineering, University of Nebraska-Lincoln, North Platte, Nebraska. Tian C. Zhang is a professor in the Department of Civil Engineering, University of Nebraska-Lincoln, Lincoln, Nebraska. Steve Ensley is a clinician in the College of Veterinary Medicine, lowa State University, Ames, lowa. 
Table 1

Commercially available implants and feed additives currently used in the beef cattle industry (Zobell et al. 2000).

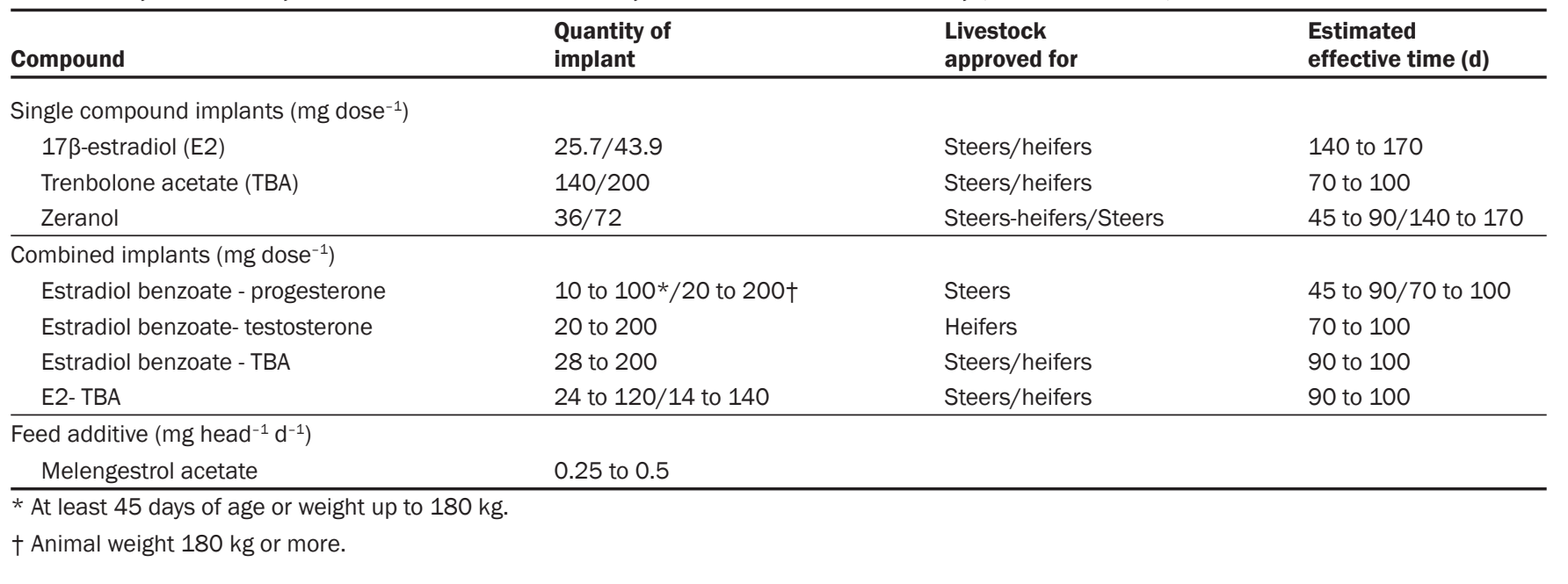

compound implants (small pellets containing GPSC that are slowly released into the blood and subsequently effect the circulation of somatotropin and insulin-like growth factor-1), 4 combined implants, and a feed additive (table 1), which are now marketed under 27 trade names. Beta agonists are also growth-promoting feed additives used by the beef cattle industry. However, they are not subject to further discussion here as they work at cellular level and do not affect the steroid hormone status of the animal.

Three naturally produced steroid hormones are used commercially as implants in cattle production, including $17 \beta$-estradiol, testosterone, and progesterone, as well as zeranol (a resorcylic acid lactone derived from zearalenone), and the synthetic anabolic steroid trenbolone acetate (TBA). Estradiol and its benzoate ester are the major class of estrogen compounds used in implants as single implant or in combination with testosterone, progesterone, or TBA. Trenbolone acetate, a synthetic androgen, has 3 to 5 times more androgenicity compared to natural testosterone (Bouffault et al. 1983). The feed additive melengestrol acetate is a synthetic progestagen and 30 to 125 times more potent than natural progesterone (Zimbelman et al. 1970).

Proper implantation techniques and sanitation are prerequisites to get optimum response from implants; thus, implant dosage and placement location in the animal are regulated by the FDA. Their use also depends on the age and sex of the animal (table 1). During the approval process, the FDA extensively studied the meat from treated animals to make sure that the meat was safe for human consumption and the drugs did not harm the treated animal (USFDA 2011).

Implant and supplement selection is based on optimum economic returns from each stage of cattle production. Generally, the average daily gain of implanted feedlot cattle is expected to increase by $15 \%$ to $20 \%$, and feed efficiency (i.e., feed intake/weight gain) by $6 \%$ to $14 \%$ (Griffin and Mader 1997). In addition to their performance-enhancing effects in the cattle industry, GPSCs may have some possible negative side effects, which include lower yield grade, udder development, bulling, raised tailheads, and vaginal and rectal prolapses. Moreover, improper implanting (i.e., crushed, missing or bunched pellets; abscesses; expelled implants; and cartilage embedment) can reduce effectiveness of implants (Griffin and Mader 1997).

\section{Major Scientific and Environmental Concerns}

Due to the occurrence of both natural and synthetic steroids from animal manure in water and their possible adverse impacts on aquatic and terrestrial life, GPSCs have become an emerging water contamination concern. Predicting transport of parent compounds from manure to water bodies can be challenging because of numerous potential chemical transformations and environmental interactions. Changes in both chemical form and concentration can occur through biological and chemical degradation processes during manure handling and field application (Colucci et al. 2001; Schiffer et al. 2001; Fan et al. 2007). Movement through the soil-water system is predominantly governed by adsorption-desorption processes (Lee et al. 2003; Casey et al. 2005; Sangsupan et al.
2006). The major GPSC pathways from animal manure to ground and surface water are shown in figure 1 . Some major concerns and questions regarding GPSCs include

- Chemical fate:What are the primary forms and relevant concentrations of GPSCs in manure, treated soil, and impacted water bodies?

- Environmental fate and transport: Where and how do GPSCs move in the environment?

- Environmental impacts:What are the endocrine-disrupting effects of GPSCs on aquatic life, terrestrial organisms, and humans?

- Potential management:What management and agricultural practices will be necessary to control the release of GPSCs to the environment?

- Regulatory measures: What regulations will be effective in limiting the movement of GPSCs from animal production facilities?

Chemical Fate of Growth-Promoting Steroids and Steroid-Like Compounds. Although in vivo biochemical transformations may become quite complex, hepatic metabolism of most GPSCs typically occur via an oxidation-reduction reaction followed by glucuronide or sulfate conjugation (Schwarzenberger et al. 1996). During metabolic conversion within cattle, the free natural estrogen $17 \beta$-estradiol is oxidized to estrone and from estrone to $17 \alpha$-estradiol by reduction (Mellin and Erb 1965, 1966). The synthetic androgen TBA is hydrolyzed to $17 \beta$-trenbolone and trendione and then thought to be excreted by cattle primarily as $17 \alpha$-trenbolone (Schiffer et al. 2001), though glucuronide forms are also known to 


\section{Figure 1}

Environmental fate of growth-promoting steroids and steroid-like compounds from animal implant to water resources.

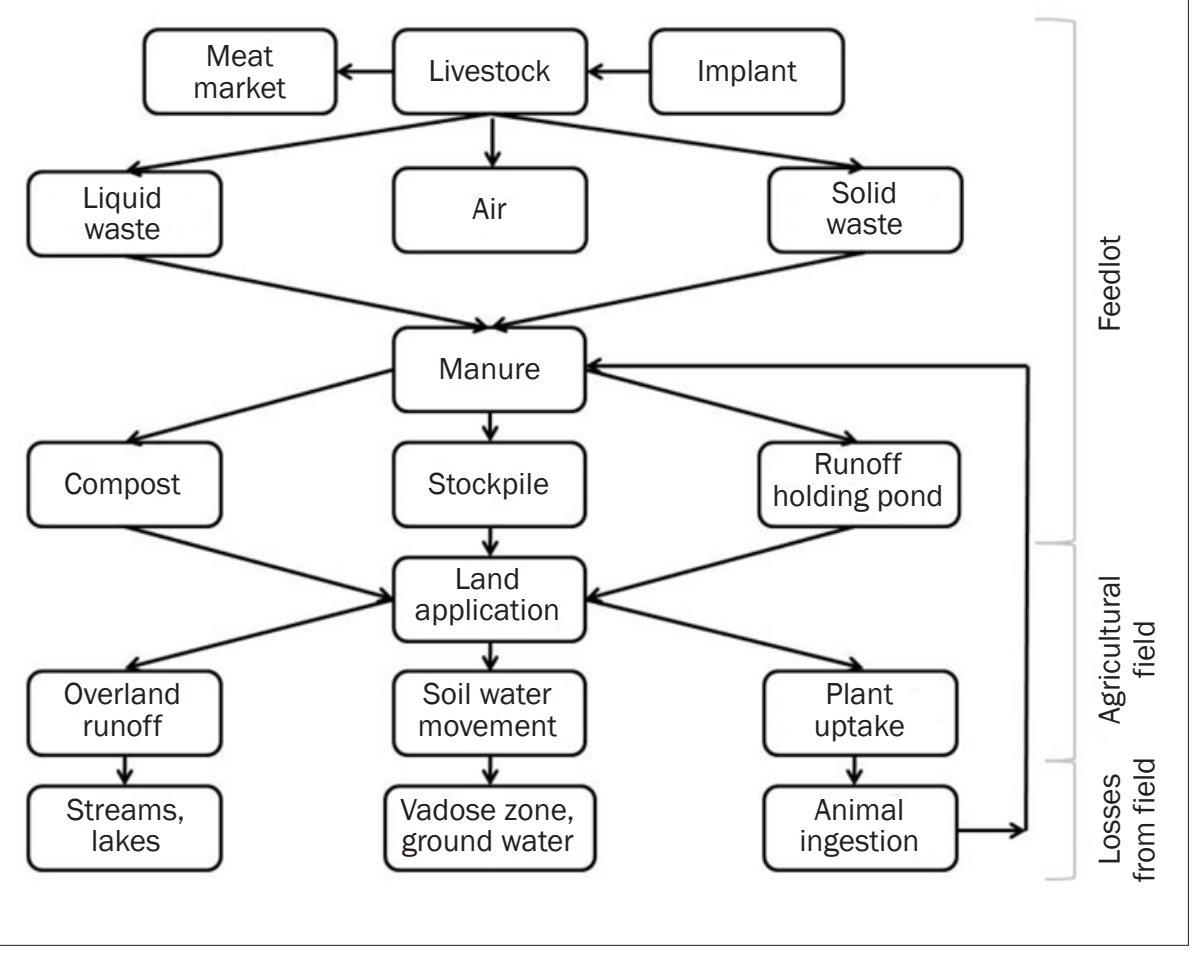

occur (Van Pouke and Van Peteghem 2002). Among the endogenous androgens, 4-androstenedione is the precursor of testosterone and forms the metabolites androsterone and 11-ketotestosterone. In addition, the primary metabolites of progesterone are $5 \alpha$ and $5 \beta$-reduced pregnanediones along with hydroxylated pregnanes (Purdy et al. 1980; Schwarzenberger et al. 1996). Melengestrol acetate is generally excreted as the parent form with very low metabolite concentrations (Krzeminski et al. 1981). One of the difficulties in identifying the specific sources of some GPSCs found in the environment is the potential for multiple sources. For example, the estrogen agonist and implant zeranol $(\alpha$-zearalanol) and its metabolites $(\beta$-zearalanol, $\alpha$-zearalenol, and $\beta$-zearalenol) can be formed by reduction of zearalenone from the resorcylic acid lactone by some species of Fusarium fungus widely found in agricultural environments (Havens et al. 2010).

The excretion pathways of GPSCs after implanting were studied by several authors using radio-labeled compounds. Using radioactive $17 \beta$-estradiol, Ivie et al. (1986) observed 58\% excretion in feces and $42 \%$ excretion in urine. Estergreen et al. (1977) found that $90 \%$ to $96 \%$ of progesterone can be excreted in feces and $4 \%$ to $10 \%$ in urine.
Pottier et al. (1981) observed 80\% excretion of injected radio-labeled trenbolone acetate in the bile. Krzeminski et al. (1981) found $87 \%$ excretion of radio-labeled melengestrol acetate from the liver where $10 \%$ to $17 \%$ remained unabsorbed and in the parent form.

After excretion in cattle feces and urine, both natural and synthetic steroids can be available in free and conjugated forms in the environment. Cattle regulate internal levels and excrete steroids and other bioactive compounds primarily through conjugation (with additional sulfate or glucuronide functional groups), which are more water soluble than unconjugated or free forms (Shore and Shemesh 2003; Lange et al. 2002). However, Schwarzenberger et al. (1996) found that conjugated forms of steroids can be deconjugated in the intestine and excreted in free forms. Additionally, after releasing into the environment, the conjugated forms can be converted back to free forms by several bacteria (D'Ascenzo et al. 2003; Yang et al. 2010; Fahrbach et al. 2010). Concentrations of the steroids and associated metabolites found in cattle manure and soil-water systems are listed in table 2 from relevant studies. Further discussion of the chemical properties of individual steroids and metabolites mentioned in this paper are presented in detail by Young and Borch (2009) and are beyond the scope of this review.

Environmental Fate and Transport of Growth-Promoting Steroids and SteroidLike Compounds. The presence of GPSCs from treated cattle has been found in feces (Lorenzen et al. 2004; Schiffer et al. 2001), liquid manure (Schiffer et al. 2001) and lagoon effluent (Irwin et al. 2001; Hutchins et al. 2007). Most animal wastes are deposited on the feedlot and may remain stored for 6 to 12 months. Solid wastes from cattle are commonly collected from the cattle facilities and applied directly to crop land or stockpiled for a variable length of time before being applied to crop land. In other production facilities, lagoons are used as holding reservoirs or anaerobic digesters for animal wastes before being applied as fertilizers to cropland (Hutchins et al. 2007). Time spent in storage in stockpiles or lagoons provides an opportunity for steroids to be impacted by photodegradation or biodegradation processes.

A summary of major scientific findings with concentrations of GPSCs and sites of detection is given in table 2. One recent study conducted in Nebraska found that the concentration in runoff from feedlot surfaces can be as high as $1,100 \mathrm{ng} \mathrm{L}^{-1}(1,100$ ppt) for $17 \beta$-estradiol, 1,050 ng $\mathrm{L}^{-1}(1,050$ $\mathrm{ppt}$ ) for estrone, $1,070 \mathrm{ng} \mathrm{L}^{-1}(1,070 \mathrm{ppt})$ for progesterone, and $420 \mathrm{ng} \mathrm{L} \mathrm{L}^{-1}$ (420 ppt) for testosterone (Bartelt-Hunt et al. 2012). From feedlot surface runoff to lagoon storage, the steroid concentrations can decline sharply because the lagoon works like an anaerobic digester. Hutchins et al. (2007) found the total free estrogen concentration was $24 \mathrm{ng}$ $\mathrm{L}^{-1}$ (24 ppt) from lagoon effluent, which was almost two orders of magnitude less than concentrations recorded in feedlot surface runoff, and is consistent with anaerobic degradation (table 2).

After land application, GPSCs and their associated compounds are subjected to a variety of physical transformations including adsorption/desorption with soil, sediment, or other particles and decay mechanisms such as biodegradation and photodegradation. According to the US Environmental Protection Agency (USEPA), each year almost 15 million $\mathrm{Mg}$ (16.5 million $\mathrm{tn})$ of cattle manure are generated from feedlots (USEPA 2001). Assuming an average application rate of $56 \mathrm{Mg} \mathrm{ha}^{-1}\left(25 \mathrm{tn} \mathrm{ac}^{-1}\right)$, this manure is spread on approximately 0.3 mil- 
Table 2

Summary of several growth-promoting steroids and steroid-like compound concentrations at different phases from source to water bodies.

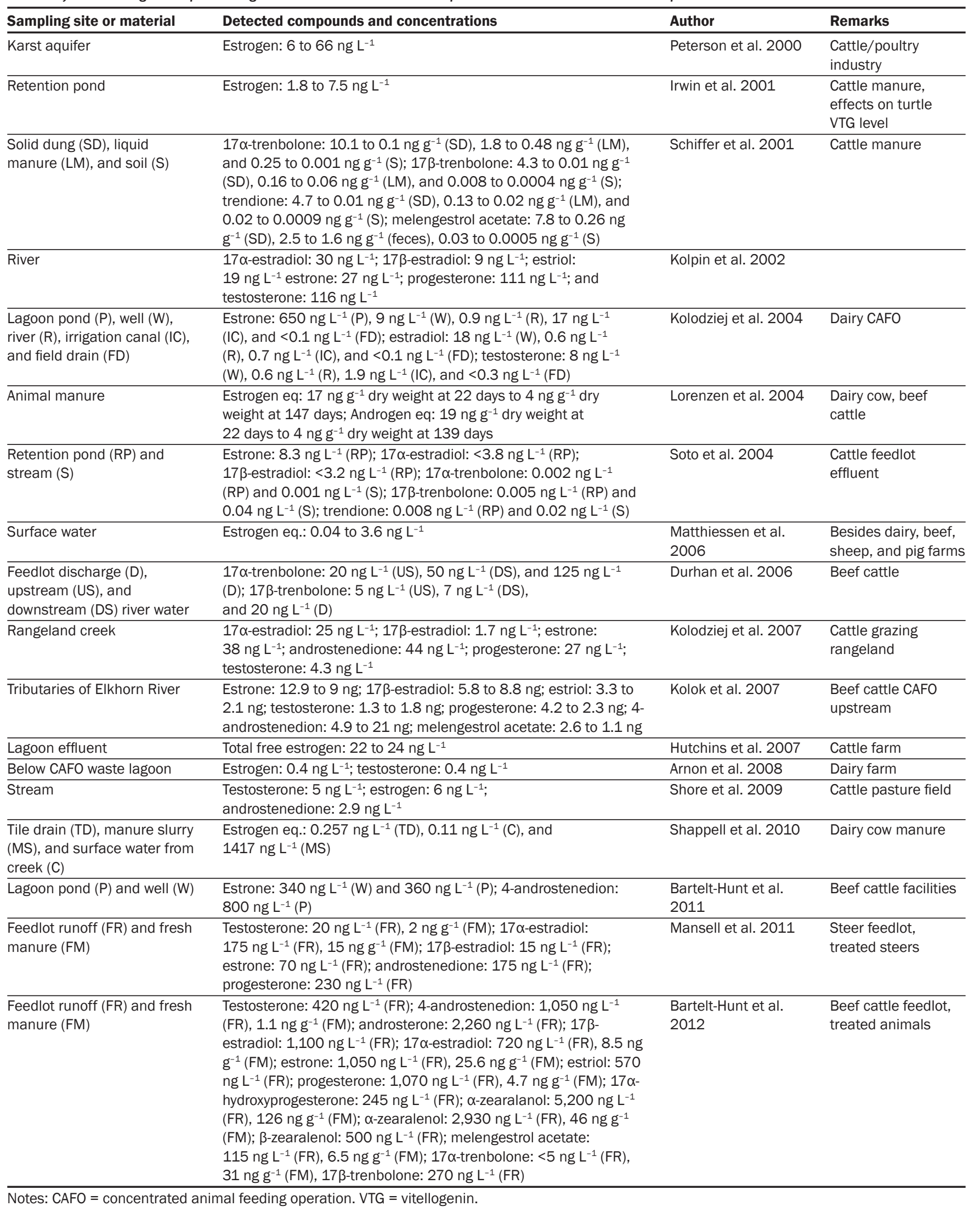


lion ha (0.7 million ac) of agricultural land. However, due to limited research on the fate and transport of GPSCs after application, the mass of GPSC applied to land remains unknown (USEPA 2001).

Several laboratory batch and column studies investigated the fate and transport of natural steroids (Colucci et al. 2001; Colucci and Topp 2002; Casey et al. 2003, 2004; Lee et al. 2003; Lai et al. 2000; Das et al. 2004; Carr et al. 2011; Lucas and Jones 2006) and synthetic steroids in soil-water systems (Khan et al. 2008). In general, the above studies found short half-life of these compounds in soil under aerobic conditions (table 3). Khan et al. (2008) found that the half-life of $17 \alpha$-trenbolone was 0.2 to 0.5 day and half-life of $17 \beta$-trenbolone was 0.2 day under aerobic degradation; however, Schiffer et al. (2001) found that trenbolone acetate can persist in soil for two months and melengestrol acetate for up to six months. Additionally, Yang et al. (2010) found six times longer half-life of testosterone under anaerobic conditions compared to aerobic conditions. When comparing the behavior of $17 \beta$-estradiol and testosterone, there is evidence that compounds with similar chemical structures behave very differently after environmental exposure. For example, testosterone degraded more rapidly than $17 \beta$-estradiol and yet there structures are similar (Casey et al. 2003, 2004). In addition, though synthetic and natural steroids and their metabolites may have similar chemical behaviors, individual compounds may need to be studied more thoroughly within a range of soil-water systems in order to understand their fate and transport.

Possible transport routes of steroids and metabolites include the overland runoff of sediment and colloids on which steroids are adsorbed (Das et al. 2004; Liu et al. 2005). Therefore, the compounds may eventually reach surface water via overland runoff or subsurface flow. Research has indicated the presence of both natural and synthetic steroids and metabolites in streams, rivers, tile drains, and drainage discharge in the vicinity of cattle feedlots (Shappell et al. 2010; Shore et al. 2009; Kolodziej et al. 2007; Kolok et al. 2007; Durhan et al. 2006; Matthiessen et al. 2006; Soto et al. 2004; Kolpin et al. 2002). In the first nationwide survey of 139 streams in 30 states across the United States in 1999 to 2000 , water samples were analyzed for 95 selected wastewater contaminants

\section{Table 3}

Half-life of several steroids in soil

\begin{tabular}{lll}
\hline Steroids & Half-life $(\mathbf{d})$ & References \\
\hline $17 \beta$-estradiol & 0.8 to 1.1 & Lee et al. 2003 \\
Estrone & 2.8 to 4.9 & Lucas and Jones 2006 \\
Estriol & 0.7 to 1.7 & Carr et al. 2011 \\
Testosterone & 0.08 to 0.8 & Lee et al. 2003 \\
$17 \alpha$-trenbolone & 0.2 to 0.5 & Khan et al. 2008 \\
$17 \beta$-trenbolone & 0.2 & Khan et al. 2008 \\
Melengestrol acetate (in cattle) & 2.5 to 3 & Lauderale et al. 1977
\end{tabular}

including 14 steroidal compounds. Estriol (median concentration $19 \mathrm{ng} \mathrm{L^{-1 }}$ [19 ppt]) was detected in $21 \%$ of the samples, followed by $17 \beta$-estradiol ( $9 \mathrm{ng} \mathrm{L}^{-1}[9 \mathrm{ppt}]$ ) in $10 \%$ of the samples (Kolpin et al. 2002). Other compounds, including $17 \alpha$-estradiol (30 ng $\mathrm{L}^{-1}$ [30 ppt]), estrone (27 ng L ${ }^{-1}$ [27 ppt]), progesterone (111 ng $\mathrm{L}^{-1}$ [111 ppt]), and testosterone (116 $\mathrm{ng} \mathrm{L^{-1 }}$ [116 ppt]), were also present in the water samples. In a more recent study, Shore (2009) detected steroids in rivers $60 \mathrm{~km} \mathrm{(37} \mathrm{mi)} \mathrm{downstream}$ from a concentrated animal feeding operation (CAFO), which provides evidence that GPSCs can impact aquatic biota over a relatively large area.

Steroids have also been detected in groundwater aquifers near cattle production facilities and monitoring wells adjacent to waste lagoons. Peterson et al. (2000) reported the presence of $17 \beta$-estradiol at concentrations ranging from 6 to $66 \mathrm{ng} \mathrm{L}^{-1}$ (6 to $66 \mathrm{ppt}$ ) in spring water discharged from a mantled karst aquifer in a region with intense poultry and cattle production facilities in northwest Arkansas. Arnon et al. (2008) studied the deep vertical distribution of steroids from an earthen unlined waste lagoon to groundwater at a dairy farm. Testosterone $\left(<3.1 \mathrm{ng} \mathrm{L}^{-1}\right.$ $[<3.1 \mathrm{ppt}])$ and estrogen $\left(<2.6 \mathrm{ng} \mathrm{L}^{-1}[<2.6\right.$ $\mathrm{ppt}])$ were detected under the waste lagoon at depth of 45 and $32 \mathrm{~m}$ (148 to $105 \mathrm{ft}$ ), respectively. These studies demonstrate the ubiquitous nature of GPSCs in both surface and groundwater bodies of the United States. Though it may be difficult to assign a specific source in each case, one cannot ignore the link to animal production facilities.

The above studies suggest that GPSCs can be lost from production facilities through several pathways, including leakage from poorly constructed lagoons, leaching through the vadose zone, and runoff from manure-amended agricultural fields. The magnitude of contamination depends on factors such as soil properties; type of GPSCs and their chemical properties; precipitation timing, duration, and intensity; antecedent soil water content; position of water table; and manure and crop management practices (Burkholder et al. 2007). Since there is evidence of these natural and synthetic steroids in manure, lagoon effluent, soil profile, and in surface and groundwater, the main concern is whether the concentrations are great enough to affect aquatic or terrestrial life.

Potential Environmental Impacts. Because of the biological nature of these compounds, the scientific community and the general population are concerned about the exposure of aquatic life and humans to steroids that can disrupt normal endocrine functions during critical growth stages (Colborn et al. 1993; Matthiessen 2003; Guillette et al. 2000; Cevasco et al. 2008; Falconer et al. 2006). Most of the evidence related to the health effects of endocrine disruption in wildlife came from species living in or in association with an aquatic environment (Tyler et al. 1998; Vos et al. 2000; Jobling et al. 1998). Adverse effects of endocrine disruption include abnormal blood hormone levels, masculinization of females, feminization of males, altered sex ratios, intersexuality, and reduced fertility in fish (Jobling et al. 2003). Moreover, continuous exposure to low hormone concentrations has also been linked to increased incidence of human cancers, sexual disorders, and decline in human male:female ratios (Miller et al. 1998; WHO 2002; Hood 2005; Mackenzie et al. 2005).

The biological effects of GPSCs on aquatic ecosystems have been studied extensively since the early 1980s with most of the research focused on fish. Fish species such as fathead minnow (Pimephales promelas), rainbow trout (Oncorhynchus mykiss), zebrafish (Danio rerio), and medaka (Oryzias latipes) have traditionally served as environmental sentinel organisms to help predict the impact on other aquatic life (Kolok and Sellin 2008). Biological effects of steroids on exposed fish 
were identified by molecular (altered sex steroids, gene expression, and plasma vitellogenin [an egg precursor protein produced in female fishes in response to endogenous estrogen production] concentrations), cellular, or tissue level (alteration of secondary sexual characteristics and gonad health) biomarkers and reduced reproductive fitness (impaired reproduction and skewed sex ratios) (Kramer et al. 1998; Routledge et al. 1998; Panter et al. 1998; Ankley et al. 2003, 2004; Thorpe et al. 2003; Seki et al. 2006; Jensen et al. 2006). Most of the studies cited above focused on the effects of $17 \beta$-estradiol and its metabolites estrone and estriol on different fish species, along with the metabolites of synthetic steroid trenbolone acetate. For example, Routledge et al. (1998) studied adult male rainbow trout and found that steroids were linked to endocrine disruption after three weeks of exposure to 1 to $10 \mathrm{ng}$ $\mathrm{L}^{-1}$ (1 to $10 \mathrm{ppt}$ ) of $17 \beta$-estradiol and 25 to $50 \mathrm{ng} \mathrm{L}^{-1}$ (25 to $50 \mathrm{ppt}$ ) of estrone. Similarly, Seki et al. (2006) found reduced development of the female plasma vitellogenin in medaka at a concentration of $40 \mathrm{ng} \mathrm{L^{-1 }}(40 \mathrm{ppt})$, in zebrafish at $351 \mathrm{ng} \mathrm{L}^{-1}$ (351 ppt), and in fathead minnow at $4,060 \mathrm{ng} \mathrm{L}^{-1}(4,060 \mathrm{ppt})$ of $17 \beta$-trenbolone under controlled laboratory conditions. Results suggest that the effect of steroids on a fish species is concentration dependent and hence can have variable impacts on aquatic life. Consequently, in situ studies are needed to further evaluate the impact of steroids on fish populations.

Based on our review, the only study available assessing the biological effect of feedlot effluent in water on wild fish species was conducted in two subwatersheds that drain into the Elkhorn River in eastern Nebraska (Cuming County) by Orlando et al. (2004). They noted a number of physiological effects in the adult fathead minnow. Two sites, one directly downstream from a large feedlot (site 1) and the other located in a stream without direct contribution from a feedlot but where manure was applied to cropland with dispersed cattle activity (site 2), were sampled at several locations and compared to an upstream reference site with no feedlot activity in the surrounding area of Oak Valley State Wildlife Management Area. Results from the study showed that male minnows from site 1 and site 2 had significantly smaller testes, diminished secondary sexual characteristics, and a reduction in testosterone synthesis compared to the reference site.
In female minnows, significant differences in defeminized sex hormone ratios were observed at site 1 and site 2 compared to the reference site based on decreased $17 \beta$-estradiol and increased testosterone synthesis. Based on these observations, they suggested a possible link between natural or synthetic steroids in water from cattle feedlot or cattle manure and sexual development in wild fish species. However, a companion study by Soto et al. (2004) attempted to measure natu$\mathrm{ral}$ and synthetic steroids in the samples from the same sites as Orlando et al. (2004) but was unsuccessful in detecting anything but estrone and estradiol. Presence of the synthetic androgen trenbolone and its associated metabolites was inconclusive in the study because of a high number of below detection level sample analysis results.

Increasing rates of human testicular and breast cancers and change in male:female ratios are believed to be linked to endocrine-disrupting chemicals including steroids (Henderson et al. 1982, 1988; WHO 2002). However, links between environmental steroid exposure and human health effects like breast cancer, prostate cancer, and reproductive impacts are inconclusive as these health effects also depend largely on diet, sexual activity, reproductive behavior, and genetic susceptibility (Weyer and Riley 2001; Hanselman et al. 2003). Considering the very low levels of natural or synthetic GPSCs found in drinking water, it seems unlikely that drinking water is an important source of exposure to humans. Nevertheless, because of the existing knowledge gaps, further research is required to determine whether links may be evident between synthetic GPSCs and occurrence of negative human health impacts.

Potential Management. Based on the above discussion and nature of the problem, it is time to take possible precautionary measures that will prevent the off-site movement of GPSCs in the environment and reduce potential adverse impact. One of the major undertakings of research and action should be directed toward how to reduce the introduction of GPSCs to water bodies. In doing so there would be a reduction in deleterious effects on aquatic life, wildlife, and potentially humans. According to Novotny (2003), major mitigation techniques for diffuse pollutants like manure-borne GPSCs include (1) source control/reduction measures, (2) BMPs to prevent movement of GPSCs, and
(3) other strategies to reduce delivery of GPSCs from the source area to the receiving water body. The following section will focus on the second point, which is based upon several BMPs, and the other two points, which are regulatory measures, will be discussed in a later section.

Several researchers have evaluated different BMPs using manure from different sources in an attempt to identify sustainable solutions to control the movement of GPSCs from agricultural fields to water bodies. After excretion by cattle, both solid and liquid waste/manure management can play a vital role to reduce the GPSC concentration in storage facilities. Potential manure-handling practices include composting over conventional stockpiling or storage in lagoon. Organic matter and presence of microorganisms such as actinobacteria (genera include Arthrobacter, Micrococcus, Mycobacterium, and Nocardia), which are commonly found in both soil and water, play a vital role in the degradation process of steroids (Young and Borch 2009). The rate of degradation depends on factors like soil temperature, $\mathrm{pH}$, nutrient content, dissolved oxygen (DO), or type of GPSCs (Yang et al. 2010).

Derby et al. (2011) showed that composting swine manure can be an effective manure management technique to reduce estrogenicity $(17 \beta$-estradiol $+0.1 \times$ estrone $)$. They found that estrogenicity was reduced $79 \%$ by composting manure during a 92-day study period whereas stockpiling reduced estrogenicity by $74 \%$. The study showed that for both cases, $17 \beta$-estradiol concentration varied over time without a decline in concentration and estrone. Initially estrone was at a much greater concentration than $17 \beta$-estradiol but decreased in concentration during the study. Yang et al. (2011) found that the swine manure-borne Proteobacteria are capable of testosterone degradation under aerobic degradation and form androstenedione, androstadienedione, and dehydrotestosterone. Using radio-labeled testosterone, they found $49 \%$ to $68 \%$ mineralization to carbon dioxide $\left(\mathrm{CO}_{2}\right)$ within 8 days of incubation.

Shappell et al. (2007) found that a lagoon-constructed wetland system at a swine farrowing facility decreased estrogenic activity by $83 \%$ to $93 \%$ and the effluent concentration of estrogen was less than $10 \mathrm{ng} \mathrm{L}^{-1}(10 \mathrm{ppt})$. Fahrbach et al. (2010) showed degradation of testosterone by Steroidobacter denitrificans under anaero- 
bic conditions, which can prevail in storage lagoons. No studies have been conducted to compare the impact of different manure handling practices on GPSC degradation. Thus, there is a need for additional research dealing with commonly used manure management practices.

Overland runoff directly from feedlots or from treated crop production areas is one of the major pathways for GPSC transport to surface water. Processes that encourage sedimentation (i.e., sedimentation ponds or catchment basins) or vegetative filter strips that trap sediment can be effective ways to reduce delivery of these compounds attached to soil particles and colloids from source areas to water bodies. Nichols et al. (1998) showed that tall fescue grass (Festuca arundinacea) filter strip lengths of $3.1,6.2$, and $18.3 \mathrm{~m}(10,20$, and $60 \mathrm{ft}$ ) reduced transport of $17 \beta$-estradiol by $79 \%, 90 \%$, and $98 \%$, respectively.

Several studies have found that tillage practices can play a significant role in reducing the movement of steroids from manureamended agricultural fields to surface water bodies. No-till has become an increasingly popular conservation practice over the last 40 years due to its soil conservation properties. In the United States, 35.6 million ha (88 million ac) or about $22 \%$ of cropland were under the no-till practice in 2009 compared to 2.23 million ha $(5.5$ million ac) in 1974 (Horowitz et al. 2010; Phillips et al. 1980). One of the major advantages of the no-till practice is that it can reduce soil erosion by $70 \%$ to $100 \%$ (Phillips et al. 1980; Dickey et al. 1984; Huggins and Reganold 2009). Since steroids are hydrophobic and strongly adsorbed to soil particles, it follows that no-till should act as an efficient tool for reducing their movement through overland runoff. This hypothesis is supported by a previous research reported by Dutta et al. (2010) who concluded that no-till management resulted in less estrogen export in surface runoff than reduced tillage using two poultry litter sources (raw and pelletized) at three application rates $\left(12.6 \mathrm{Mg} \mathrm{ha}^{-1}\left[5.6 \mathrm{tn} \mathrm{ac}^{-1}\right]\right.$ for pelletized litter and 23 and $35 \mathrm{Mg} \mathrm{ha}^{-1}$ [10.3 and $15.6 \mathrm{tn} \mathrm{ac}^{-1}$ ] for raw litter). They also established that export of estrogens in surface runoff was much lower for pelletized poultry litter compared to raw litter. In a similar study, Jenkins et al. (2009) evaluated the potential impact of poultry litter application on estradiol and testosterone concentrations in subsurface drainage and surface runoff from irrigated crop land under no-till and conventional till management systems. They found less estradiol and testosterone in runoff from no-till than from conventional tillage.

Studies summarized above mentioned several BMPs to reduce the off- and on-site losses of GPSCs to the environment. Since animals excrete natural steroids, BMPs designed to prevent off-site movement of GPSCs will also reduce natural steroid loss to the environment. Best management practices are often highly site specific and depend largely on local conditions, such as variation in climatic conditions, soil texture, topography, land use, ecology, and agricultural practices. Thus, knowledge from previous studies can be used to design suitable BMPs under site-specific conditions as possible mitigation techniques of feedlot cattle-generated steroid movement in agricultural systems. The USEPA's Comprehensive Nutrient Management Planning process includes these BMPs and others that when combined should reduce or eliminate transport of steroids to water bodies in the future.

Regulatory Measures. The two other mitigation techniques proposed by Novotny (2003) are basically regulatory measures to control discharge from the source into the receiving water bodies. In the United States, the USEPA regulates the pollutant discharge from source areas to water bodies under several water quality protection laws. The USEPA also controls the allowable maximum concentration of chemicals in receiving water bodies to preserve the quality for particular purposes such as public water supplies, recreation, and aquatic life. However, there are no current regulations regarding the movement of GPSCs in any of US laws or regulations. Some of the existing guidelines/laws mentioned in the following paragraphs could be used as models for regulating GPSC movement in the environment.

The Clean Water Act (CWA), formerly known as the Federal Pollution Control Act, was established in 1948 as a basic structure for regulating the quality standards and discharges of pollutants into the waters of the United States. The Act was significantly reorganized and expanded in 1972 and renamed with amendment in 1977 Under the CWA, the USEPA has set water quality standards for contaminants in surface waters (USEPA 2011a). The National Pollutant Discharge Elimination System (NPDES) permit program authorized by the
CWA controls water pollution by regulating point sources like municipal wastewater treatment plants and CAFOs that discharge pollutants into waters of the United States (USEPA 2011b). The CWA made it unlawful to discharge any pollutant from a point source into navigable waters unless a permit was obtained from the USEPA. Though the NPDES permits address the movement of various contaminants, due to insufficient information GPSC discharges are not regulated in the latest Nutrient Management Plan under the revised NPDES permit regulations and Effluent Limitation Guidelines for CAFOs released in 2008.

In water quality planning and management, pollutant assimilation capacity of the receiving water body is an important concept (Novotny 2003). The regulatory community uses the term Total Maximum Daily Load (TMDL), which is defined as the maximum amount of a pollutant that a water body can receive on a daily basis and meet the established water quality standards for the intended use of the water body (USEPA 2011c). Currently there are TMDL guidelines and regulations for many pathogens, nutrients, sediment, metals, dissolved oxygen, temperature, $\mathrm{pH}$, pesticides, and polychlorinated biphenyls under the CWA (303d). A total of 112 contaminants have Maximum Contaminant Levels delineated under the National Primary Drinking Water Regulations, but no GPSCs are included in the listing (USEPA 2011d). Development of TMDLs for GPSCs by the USEPA would be a notable achievement toward recognizing the problem and would eventually lead to setting enforceable Maximum Contaminant Levels for drinking water. However, several estrogens are already listed by the Unregulated Contaminant Monitoring Rule program in the Contaminant Candidate List-3. The purpose of the program is to list the contaminants that may require regulation under the Safe Drinking Water Act (USEPA 2012).

Among other countries studying the fate and transport of both natural and synthetic GPSCs in natural ecosystems, the Environmental Agency of the United Kingdom reviewed the properties, uses, fate, behavior, aquatic toxicity, and bioaccumulation potential of steroid estrogens and made some recommendations for protection of aquatic life in 2000 (UKEA 2004). In the Toxicity Identification and Evaluation stud- 
ies, Predicted-No-Effect-Concentrations (the concentration below which a specified percentage of species in an ecosystem are expected to be protected; PNECs) of natural estrogenic steroids were proposed for the protection of aquatic life. The proposed PNEC for $17 \beta$-estradiol was $1 \mathrm{ng} \mathrm{L^{-1 }}$ (1 ppt) as an annual average for protection of both fresh water and saltwater life. For estrone, the PNEC was 3 to $5 \mathrm{ng} \mathrm{L}^{-1}$ ( 3 to $5 \mathrm{ppt}$ ) as a provisional target. This was based on its three to five times less relative potency compared with $17 \beta$-estradiol. However, no information about synthetic steroids was included in the PNEC listing. The only other synthetic hormone included was $17 \alpha$-ethynyl estradiol, which is used by humans and is more persistent in surface water. The PNEC was set at $0.1 \mathrm{ng} \mathrm{L}^{-1}(0.1 \mathrm{ppt})$ for this compound. In a separate study in Israel, Barel-Cohen et al. (2006) reported $10 \mathrm{ng} \mathrm{L}^{-1}(10 \mathrm{ppt})$ as the Lowest Observable Effect Level (the lowest concentration or amount of a substance found by experiment or observation that causes any alteration in morphology, functional capacity, growth, development, or life span of target organisms distinguishable from normal (control) organisms of the same species and strain under the same defined conditions of exposure) for estrogen (17 $\beta$ $\mathrm{E} 2+$ estrone) due to the physiological effects on fish and plants.

One difficulty in drawing comparisons between steroid levels reported in various studies is that the researchers did not use a standard method to determine the GPSC concentrations in water or wastewater. The USEPA does have suggested methods for steroid analysis including USEPA Method 1698 and USEPA Method 539, though these have not seen widespread use. As with most emerging contaminants, researchers publish results using a variety of sampling and analytical techniques (high-performance liquid chromatography, yeast estrogen screen, enzyme-linked immunosorbent assay, liquid chromatography tandem mass spectrometry, and gas chromatography tandem mass spectrometry). Each method has advantages and disadvantages, and often differences in detection limits are critical for accurate measurement. As an example, the USEPA determines steroids in aqueous, soil, and biosolids according to USEPA Method 1698 by isotope dilution and internal standard high resolution gas chromatography combined with high resolution mass spectrometry under the
CWA program (USEPA 2007). Afterwards, in 2010, the USEPA released another guideline under Method 539 for determination of steroids in drinking water by solid phase extraction and liquid chromatography electrospray ionization tandem mass spectrometry (USEPA 2010). Because analytical technologies continue to evolve and improve, method detection limits are likely to decrease as well. Therefore, in order to establish meaningful regulatory oversight, it is essential to establish a standard protocol for analyzing steroids in manure, soil, and water.

In summary, GPSCs have drawn the attention of the scientific community on both sides of Atlantic. However, more research needs to be conducted to develop a standard chemical analysis procedure that could lead to effective regulatory measures to control GPSC movement in the environment.

Economic and Environmental Significance The United States is the world's largest producer of beef with approximately 25\% of the market (USDA 2012). Every year US cattle producers raise an estimated 33 million head of cattle in feedlots with roughly 96\% receiving GPSCs (USDA 2000). It costs about US $\$ 1$ to US $\$ 3$ per head to treat the animals, and the treatment increases the animal's growth rate by about 20\% (Raloff 2002). Treated cattle reach market weight roughly 30 to 40 days sooner than untreated cattle. The overall average rate of gain for treated animals is approximately $1.4 \mathrm{~kg} \mathrm{~d}^{-1}$ $\left(3 \mathrm{lb} \mathrm{day}^{-1}\right.$ ) with 15\% less feed consumed than an untreated animal (Raloff 2002). Therefore, the increased profit due to GPSC use ranges from US $\$ 15$ to US $\$ 40$ per animal (USDA 2000). According to a recent study by Cooprider et al. (2011), after consuming $393 \mathrm{~kg}$ (866 lb) less dry matter, GPSCtreated cattle carcasses had larger rib eye area compared to untreated cattle. Similarly, Bartelt-Hunt et al. (2012) found that though GPSC-free cattle had numerically greater percentage of USDA choice and prime carcasses, GPSC treated cattle had 6.7\% lower cost of gains. Thus, the use of GPSCs enables cattle producers to produce more beef with fewer animals and at a lower cost.

The economic advantage of using GPSCs is also significant to consumers. Even though the demand and popularity of unimplanted (natural and organic) beef is increasing in the United States, the market share is still small with respect to the total retail market. From a research brief in March through April of 2006 by the National Cattlemen's Beef Association (NCBA 2006), the natural and organic beef market comprised only about $1.1 \%$ of the total beef weight and $1.7 \%$ of the total value of retail beef sold during a quarter in 2005. The study also showed that the price of all beef products offered in retail supermarkets averaged US $\$ 7.83 \mathrm{~kg}^{-1}$ (US\$3.6 $\mathrm{lb}^{-1}$ ) compared to a natural and organic beef products price of US $\$ 11.42 \mathrm{~kg}^{-1}$ $\left(\mathrm{US} \$ 5.2 \mathrm{lb}^{-1}\right)$. Moreover, the price of natural and organic beef increased nearly $25 \%$ while the total beef price increased approximately $20 \%$ during a period from first-quarter of 2003 to fourth quarter of 2005. Therefore, it can be concluded that the use of GPSCs by the beef cattle industry is allowing more economical cattle production, thus minimizing consumer beef prices.

It is estimated that terminating the use of GPSCs would result in a loss of nearly a billion US dollars annually. However, use of GPSCs in beef cattle production can result in some environmental benefits. Considering a manure production rate of $22 \mathrm{~kg}$ animal ${ }^{-1}$ $\mathrm{d}^{-1}$ (48 $\mathrm{lb}$ animal $\left.{ }^{-1} \mathrm{day}^{-1}\right)$, each treated animal excretes $770 \mathrm{~kg}(350 \mathrm{lb})$ less manure to reach market weight an average of 35 days earlier than untreated cattle. Lower manure generation averts significant quantity of nutrient losses to the environment which may associated with lake eutrophication, excessive biochemical oxygen demand in surface water, reduced biodiversity, and problems of odors and tastes. It is estimated that there can be approximately $60 \%$ loss of nitrogen $(\mathrm{N}), 50 \%$ loss of phosphorus $(\mathrm{P})$, and $35 \%$ loss of potassium $(\mathrm{K})$ on dry weight basis through volatilization, runoff, or leaching from land areas receiving cattle manure (USEPA 2004). Thus, apart from the potential adverse impacts on aquatic and terrestrial life, use of GPSCs may have environmental and economic benefits that require a complete life-cycle analysis of these compounds.

\section{Ongoing Research}

In 1996, the USEPA initiated the Endocrine Disruptors Research Program (EDRP) in response to a congressional mandate included in the Food Quality Protection Act and Safe Drinking Water Act Amendments. The EDRP program was to provide scientific information required to mitigate or prevent the risk of chemical exposure to humans and wildlife. The EDRP is addressing three 
long-term goals as part of their multiyear plan: (1) develop a better understanding of the science underlying the effects, exposure, assessment, and management of endocrine disruptors; (2) determine the extent of the impact of endocrine disruptors on humans, wildlife, and the environment; and (3) support the USEPA's screening and testing program (USEPA 2008). Based on the preliminary study and complementing the ongoing research by USEPA's Office of Research and Development, a decade later, in 2006, USEPA granted US $\$ 5$ million under the Science To Achieve Results (STAR) program to study the "Fate and Effects of Hormones in Waste from Concentrated Animal Feeding Operations" to seven universities and collaborating organizations in different geographic regions of the country. The objectives of the STAR program are to develop robust analytical methods to quantify the GPSC concentrations, identify ecologically relevant biomarkers in aquatic species, evaluate the occurrence and risks of GPSCs associated with animal waste (cattle, swine, and poultry), and develop new or improved animal waste handling (e.g., lagoon storage, manure pit, and composting) and risk management technologies. A brief description of the research project assigned to each university is given at the STAR program website (USEPA 2011e). In summary, the USEPA through the STAR program has taken a holistic and integrated approach to identify the nature of the problem by studying the characteristics of the chemicals, their movement mechanisms, adverse impacts, and possible mitigation techniques. Therefore, it is expected that completion of the studies will provide information to develop formal regulatory and mitigation approaches.

\section{Conclusion}

In the above discussion, we present some implications of the beef cattle industry's use of GPSCs in the United States. Several studies have found the connection between beef cattle production facilities and the occurrence of various GPSCs in surface and groundwater. Different loss routes of GPSCs are shown in figure 1 , but it is still difficult to accurately predict the most likely path of GPSCs in the environment. The bioavailable form and concentration of GPSCs and their fate and transport mechanisms in soil-water systems are still under investigation. Furthermore, table 2 documents the ubiqui- tous nature of GPSCs from animal manure to water. Studies have found a connection between the presence of these chemicals in water and adverse endocrine-disrupting effects on aquatic and terrestrial life. However, cattle are not the only source of these chemicals; hence, precautionary measures can have significant economic impact on the beef cattle industry and may not produce the desired results. The contribution from the cattle industry has to be put in the perspective of how GPSCs reach surface and groundwater and whether steps are available to eliminate GPSC movement from production-related facilities. Several potential BMPs include using lagoons or holding reservoirs to store feedlot runoff, manure composting to provide time for GPSCs to degrade, and no-till cropping systems and vegetative buffer strips to keep GPSCs out of surface water bodies. Also cited are potential regulations and guidelines that could incorporate GPSCs in order to reduce GPSC losses to the environment.

The economic advantages of GPSCs to producers include greater growth rates and improved feed efficiency. From the consumer's point of view, lower beef prices result from GPSC use. However, in spite of their economic value, the environmental issues associated with GPSC use are important consequences and need to be properly addressed by regulatory requirements. Thus, a multidiscipline environmental impact assessment and life-cycle analysis should be carried out to further develop an action plan that will be successful. A more complete understanding of these chemicals and cooperative work among regulatory agencies, universities, livestock owners, commodity groups, and other environmental organizations are necessary to find a sustainable solution to this complex issue.

\section{References}

Ankley, G.T., D.L. Defoe, M.D. Kahl, K.M. Jensen, E.A Makynen, A. Miracle, P. Hartig, L.E. Gray, M. Cardon, and V. Wilson. 2004. Evaluation of the model antiandrogen flutamide for assessing the mechanistic basis of responses to an androgen in the fathead minnow (Pimephales promelas). Environmental Science \& Technology 38:6322-6327.

Ankley, G.T., K.M. Jensen, E.A. Makynen, M.D. Kahl, J.J Korte, M.W. Hornung, T.R. Henry, J.S. Denny, R.L. Leino, V.S. Wilson, M.C. Cardon, P.C. Hartig, and L.E. Gray. 2003. Effects of the androgenic growth promoter $17 \beta$-trenbolone on fecundity and reproductive endocrinology of the fathead minnow. Environmental Toxicology \& Chemistry 22:1350-1360.

Arnon, S, O. Dahan, S. Elhanany, K. Cohen, I. Pankratov,

A. Gross, Z. Ronen, S. Baram, and L.S. Shore. 2008.

Transport of testosterone and estrogen from dairy farm waste lagoons to groundwater. Environmental Science \& Technology 42:5521-5526.

Barel-Cohen, K., L.S. Shore, M. Shemesh, A. Wenzel, J. Mueller, and N. Kronfeld- Schor. 2006. Monitoring of natural and synthetic hormones in a polluted river. Journal of Environmental Management 78:16-23.

Bartelt-Hunt, S., D. Snow, T. Damon-Powell, and D. Miesbach. 2011. Occurrence of steroid hormones and antibiotics in shallow groundwater impacted by livestock waste control facilities. Journal of Contaminant Hydrology 123:94-103.

Bartelt-Hunt, S., D. Snow, W. Kranz, T. Mader, C. Shapiro, S. van Donk, D. Shelton, D. Tarkelson, and T.C. Zhang. 2012. Effect of growth promotants on the occurrence of steroid hormones on feedlot soils and in runoff from beef cattle feeding operations. Environmental Science \& Technology, doi:10.1021/ es202680q.

Bouffault, J.C., and J.P. Willemart. 1983. Anabolic activity of trenbolone acetate alone or in association with estrogens. In Anabolics in Animal Production, ed. E. Meissonnier, 193-212. Levallois, France: Office International des Epizooties.

Burkholder, J., B. Libra, P. Weyer, S. Heathcote, D. Kolpin, P.S. Thorne, and M. Wichman. 2007. Impacts of waste from concentrated animal feeding operations on water quality. Environmental Health Perspectives 115:308-312.

Carr, D.L., A.N. Morse, J.C. Zak, and T. A. Anderson. 2011. Microbially mediated degradation of common pharmaceuticals and personal care products in soil under aerobic and reduced oxygen conditions. Water, Air, \& Soil Pollution 216:633-642.

Casey, F.X.M., H. Hakk, J. Simunek, and G.L. Larsen. 2004. Fate and transport of testosterone in agricultural soils. Environmental Science \& Technology 38:790-798.

Casey, F.X.M., G.L. Larsen, H. Hakk, and J. Simunek. 2003. Fate and transport of $17 \beta$-estradiol in soil-water systems. Environmental Science \& Technology 37:2400-2409.

Casey, F.X.M., J. Simunek, J. Lee, G.L. Larsen, and H. Hakk. 2005. Sorption, mobility, and transformation of estrogenic hormones in natural soil. Journal of Environmental Quality 34(4):1372-1379.

Cevasco, A., R. Urbatzka, S. Bottero, A. Massari, F. Pedemonte, W. Kloas, and A. Mandich. 2008. Endocrine disrupting chemicals (EDC) with (anti)estrogenic and (anti)androgenic modes of action affecting reproductive biology of Xenopus leavis: II. Effects on gonad histomorphology. Comparative Biochemistry and Physiology Part C 147:241-251.

Colborn, T., F.S.V. Saal, and A.M. Soto. 1993. Developmental effects of endocrine-disrupting chemicals in wildlife 
and humans. Environmental Health Perspectives 101(5): 378-384.

Colucci, M.S., H. Bork, and H. Topp. 2001. Persistence of estrogenic hormones in agricultural soils: I. 17-estradiol and estrone. Journal of Environmental Quality 30:2070-2076.

Colucci, M.S., and E. Topp. 2002. Dissipation of part-pertrillion concentrations of estrogenic hormones from agricultural soils. Canadian Journal of Soil Science 82:335-340.

Cooprider, K., F. Mitloehner, T. Famula, E. Kebreab, Y. Zhao, and A. Van Eenennaam. 2011. Feedlot efficiency implications on greenhouse gas emissions and sustainability. Journal of Animal Science 89:2643-2656.

Das, B.S., L.S. Lee, P.S.C. Rao, and R.P. Hultgren. 2004. Sorption and degradation of steroid hormones in soils during transport: column studies and model evaluation. Science of the Total Environment 38:1460-1470.

D’Ascenzo, G., A. Di Corcia, A. Gentili, R. Mancini, R. Mastropasqua, M. Nazzari, and R. Samperi. 2003. Fate of natural estrogen conjugates in municipal sewage transport and treatment facilities. Science of the Total Environment 302:199-209.

Derby, N.E., H. Hakka, F.X.M. Casey, and T.M. DeSutter. 2011. Effects of composting swine manure on nutrients and estrogens. Soil Science 176(2):91-98.

Dickey, E.C., D.P. Shelton, P.J. Jasa, and T.R. Peterson. 1984. Tillage, residue and erosion on moderately sloping soils. Transactions of the American Society of Agricultural Engineers 27(4):1093-1099.

Durhan, E.J., C. S. Lambright, E.A. Makynen, J. Lazorchak, P.C. Hartig, V.C. Wilson, L.E. Gray, and G.T. Ankley. 2006. Identification of metabolites of trenbolone acetate in androgenic runoff from a beef feedlot. Environmental Health Perspectives 114(supplement 1):65-68.

Dutta, S., S. Inamdar, J. Tso, D.S. Aga, and J.T. Sims. 2010. Free and conjugated estrogen exports in surfacerunoff from poultry litter-amended soil. Journal of Environment Quality 39(5):1688-1698.

Estergreen, V.L., M.T. Lin, E.L. Martin, G.E. Moss, A.L. Branen, L.O. Luedecke, and W. Shimoda. 1977. Distribution of progesterone and its metabolites in cattle tissues following administration of progesterone-4${ }^{14} \mathrm{C}^{1,2,3,4}$. Journal of Animal Science 46:642-651.

Fahrbach, M., M. Krauss, A. Preiss, H.E. Kohler, and J. Hollender. 2010. Anaerobic testosterone degradation in Steroidobacter denitrificans- identification of transformation products. Environmental Pollution 158: 2572-2581.

Falconer, I.R., H.F. Chapman, M.R. Moore, and G. Ranmuthugala. 2006. Endocrine-disrupting compounds: A review of their challenge to sustainable and safe water supply and water reuse. Environmental Toxicology 21:181-191.

Fan, Z.S., F.X.M. Casey, H. Hakk, and G.L. Larsen. 2007. Persistence and fate of $17 \beta$ - estradiol and testosterone in agricultural soils. Chemosphere 67(5):886-895.
Griffin, D., and T. Mader. 1997. Beef Cattle Implant Update. Cooperative Extension Bulletin G97-1324-A. Lincoln, NE: University of Nebraska.

Guillette, L.J., Jr., D.A. Gain, M. Gunderson, S. Kools, M.R. Milnes, E.F. Orlando, A.A. Rooney, and A.R. Woodward. 2000. Alligators and endocrine disrupting contaminants: A current perspective. American Zoologist 40:438-452.

Hanselman, T.A., D.A. Graetz, and A.C. Wilkie. 2003. Manure-borne estrogens as potential environmental contaminants: A review. Environmental Science \& Technology 37:5471-5478.

Havens, S.M., C.J. Hedman, J.D.C. Hemming, M.G. Mieritz, M.M. Shafer, and J.J. Schauer. 2010. Stability, preservation, and quantification of hormones and estrogenic and androgenic activities in surface water runoff. Environmental Toxicology and Chemistry 29(11):2481-2490

Henderson, B.E., R. Ross, and L. Bernstein. 1988. Estrogens as a cause of human cancer: The Richard and Hinda Rosenthal foundation award lecture. Cancer Research 48:246-253.

Henderson, B.E., R.K. Ross, M.C. Pike, and J.T. Casagrande. 1982. Endogenous hormones as a major factor in human cancer. Cancer Research 42:3232-3239.

Hood, E. 2005. Are EDCs blurring issues of gender? Environmental Health Perspectives 113:A670-A677.

Horowitz, J., R. Ebel, and K. Ueda. 2010. "No-till" farming is a growing practice. Economic Information Bulletin Number 70. Washington, DC: USDA, Economic Research Service.

Huggins, D.R., and J.P. Reganold. 2008. No-till: The quiet revolution. Scientific American 299:70-77.

Hutchins, S.R., M.V. White, F.M. Hudson, and D.D. Fine. 2007. Analysis of lagoon samples from different concentrated animal feeding operations for estrogens and estrogen conjugates. Environmental Science \& Technology 41(3):738-744.

Irwin, L. 2001. Vitellogenin induction in painted turtle, Chrysemys picta, as a biomarker of exposure to environmental levels of estradiol. Aquatic Toxicology 55(1-2):49-60

Ivie, G.W., R.J. Christopher, C.E. Munger, and C.E. Coppock. 1986. Rate and residues of $\left[4-{ }^{14} \mathrm{C}\right]$ esteradiol$17 \beta$ after intramuscular injection into Holstein steer calves. Journal of Animal Science 62:618-690.

Jenkins, M.B., D.M. Endale, H.H. Schomberg, P.G. Hartel, and M.L. Cabrera. 2009. 17 $\beta$-Estradiol and testosterone in drainage and runoff from poultry litter applications to tilled and no-till crop land under irrigation. Journal of Environmental Management 90(8):2659-2664.

Jenkins, R.L., E.M. Wilson, R.A. Angus, W.M. Howell, and M. Kirk. 2003. Androstenedione and progesterone in the sediment of a river receiving paper mill effluent. Toxicological Sciences 73(1):53-59.

Jensen, K.M., E.A. Makynen, M.D. Kahl, and G.T. Ankley. 2006. Effects of the feedlot contaminant $17 \alpha$-trenbolone on reproductive endocrinology of the fathead minnow. Environmental Science \& Technology 40:3112-3117.

Jobling, S., M. Nolan, C.R. Tyler, G.C. Brighty, and J.P. Sumpter. 1998. Widespread sexual disruption in wild fish. Environmental Science \& Technology 32:2498-2506.

Jobling, S., and C.R. Tyler. 2003. Endocrine disruption in wild freshwater fish. Pure and Applied Chemistry 75(11):2219-2234.

Khan, B., L. Lee, and A. Sassman. 2008. Degradation of synthetic androgens $17 \alpha$-and $17 \beta$-trenbolone and trendione in agricultural soils. Environmental Science \& Technology 42(10):3570-3574.

Kolodziej, E.P., T. Harter, and D.L. Sedlak. 2004. Dairy wastewater, aquaculture, and spawning fish as sources of steroid hormones in the aquatic environment. Environmental Science \& Technology 38(23):6377-6384

Kolodziej, E.P., and D.L. Sedlak. 2007. Rangeland grazing as a source of steroid hormones to surface waters. Environmental Science \& Technology 41(10):3514-3520.

Kolok, A.S., and M.K. Sellin. 2008. The environmental impact of growth-promoting compounds employed by the United States beef cattle industry: History, current knowledge, and future directions. Reviews of Environmental Contamination and Toxicology 195:1-30.

Kolok, A.S., D.D. Snow, S. Kohno, M.K. Sellin, and L.J. Guillette Jr. 2007. Occurrence and biological effect of exogenous steroids in the Elkhorn River, Nebraska, USA. The Science of the Total Environment 388(1-3):104-115.

Kolpin, D.W., E.T. Furlong, M.T. Meyer, E.M. Thurman, S.D. Zaugg, L.B. Barber, and H.T. Buxton. 2002. Pharmaceuticals, hormones, and other organic wastewater contaminants in US streams, 1999-2000: A national reconnaissance. Environmental Science \& Technology 36(6):1202-1211.

Kramer, V.J., S. Miles-Richardson, S.L. Pierens, and J.P. Giesy. 1998. Reproductive impairment and induction of alkaline-labile phosphate, a biomarker of estrogen exposure, in fathead minnows (Pimephales promelas) exposed to waterborne 17 $\beta$-estradiol. Aquatic Toxicology 40:335-360.

Krzeminski, L.F., B.L. Cox, and R.E. Gosline. 1981. Fate of radioactive melengestrol acetate in the bovine. Journal of Agricultural and Food Chemistry 29(2):387-391.

Lai, K.M., K.L. Johnson, M.D. Scrimshaw, and J.N. Lester. 2000. Binding of waterborne steroid estrogens to solid phases in river and estuarine systems. Environmental Science \& Technology 34(18):3890-3894.

Lange, I.G., A. Daxenberger, B. Schiffer, H. Witters, D. Ibarreta, and H.H.D. Meyer. 2002. Sex hormones originating from different livestock production systems: Fate and potential disrupting activity in the environment. Analytica Chimica Acta 473(1-2):27-37. 
Lauderdale, J.W., L.S. Goyings, L.F. Krzeminski, and R.G. Zimbelman. 1977. Studies of a progestogen (MGA) as related to residues and human consumption. Journal of Toxicology and Environmental Health 3:5-33.

Lee, L.S., T.J. Strock, A.K. Sarmah, and P.S.C. Rao. 2003. Sorption and dissipation of testosterone, estrogens, and their primary transformation products in soils and sediment. Environmental Science \& Technology 37(18):4098-4105.

Liu, R., A. Wilding, A. Hibberd, and J.L. Zhou. 2005. Partition of endocrine-disrupting chemicals between colloids and dissolved phase as determined by cross-flow ultrafiltration. Environmental Science \& Technology 39(8):2753-2761.

Lorenzen, A., J.G. Hendel, K.L. Conn, S. Bittman, A.B. Kwabiah, G. Lazarovitz, D. Masse D, T.A. McAllister, and E. Topp. 2004. Survey of hormone activities in municipal biosolids and animal manures. Environmental Toxicology 19:216-225.

Lucas, S.D., and D.L. Jones. 2006. Biodegradation of estrone and $17 \beta$-estradiol in grassland soils amended with animal wastes. Soil Biology \& Biochemistry 38:2803-2815.

Mackenzie, C.A., A. Lockridge, and M. Keith. 2005. Declining sex ratio in a first nation community. Environmental Health Perspectives 113:1295-1298.

Matthiessen, P. 2003. An historical perspective on endocrine disruption in wildlife. Pure and Applied Chemistry 75:2197-2206.

Matthiessen, P., D. Arnold, A.C. Johnson, T.J. Pepper, T.G. Pottinger, and K.G.T. Pulman. 2006. Contamination of headwater streams in the United Kingdom by oestrogenic hormones from livestock farms. Science of Total Environment 367:616-630.

Miller, W.R., and R.M. Sharpe. 1998. Environmental oestrogens and human reproductive cancers. EndocrineRelated Cancer 5:69-96.

Mellin, T.N., and R.E. Erb. 1965. Estrogens in the bovine: A review. Journal of Dairy Science 48:687-700.

Mellin, T.N., and R.E. Erb. 1966. Estrogen metabolism and excretion during the bovine estrous cycle. Steroids 7:589-603.

NCBA (National Cattlemen's Beef Association). 2006. Niche beef products comprise small share of total retail beef sales. Washington, DC: National Cattlemen's Beef Association. http://www.beefusa.org/uDocs/ nichebeefproducts-revised.pdf.

Nichols, D.J., T.C. Daniel, D.R. Edwards, P.A. Moore, and D.H. Pote. 1998. Use of grass filter strips to reduce $17 \beta$-estradiol in runoff from fescue-applied poultry litter. Journal of Soil and Water Conservation 53(1):74-77.

Novotny, V. 2003. Water Quality: Diffuse Pollution and Watershed Management. New York: John Wiley and Sons. Orlando, E.F.,A.S. Kolok, G. Binzcik, J.L. Gates, M.K. Horton, C.S. Lambright, L.E. Gray, and L.J. Guillette. 2004. Endocrine-disrupting effects of cattle feedlot effluent on an aquatic sentinel species, the fathead minnow. Environmental Health Perspectives 112:353-358.
Panter, G.H., R.S. Thompson, and J.P. Sumpter. 1998 Adverse reproductive effects in male fathead minnows (Pimephales promelas) exposed to environmentally relevant concentrations of the natural oestrogens, oestradiol and oestrone. Aquatic Toxicology 42:243-253.

Peterson, E.W., R.K. Davis, and H.A. Orndorff. 2000 $17 \beta$-Estradiol as an indicator of animal waste contamination in mantled karst aquifers. Journal of Environmental Quality 29:826-834

Phillips, R.E., R.L. Blevins, G.W. Thomas, W.W. Frye, and S.H. Phillips. 1980. No-tillage agriculture. Science 208:1108-1113

Pottier, J., C. Cousty, R.J. Heitzman, and P. Reynolds. 1981. Differences in the biotransformation of a 17ß-hydroxylated steroid, trenbolone acetate in rat and cow. Xenobiotica 11:489-500.

Preston, R.L. 1999. Hormone containing growth promoting implants in farmed livestock. Advanced Drug Delivery Reviews 38:123-138.

Purdy, R.H., C.K. Durocher, P.H. Moore Jr., and P.N Rao. 1980. Analysis of metabolites of progesterone in bovine liver, kidney, kidney fat, and milk by high performance liquid chromatography. Journal of Steroid Biochemistry 13(11):1307-1315.

Raloff, J. 2002. Hormones: Here's the beef. Science News 161:10-12.

Raun, A.P., and R.L. Preston. 1997. History of hormonal modifier use. Symposium: Impact of implants on performance and carcass value of beef cattle, P-957, Oklahoma Agricultural Experimental Station, Division of Agricultural Sciences and Natural Resources. Stillwater, OK: Oklahoma State University.

Renner, R. 2002. Do cattle growth hormones pose an environmental risk? Environmental Science \& Technology 36:194A-197A.

Routledge, E.J., D. Sheahan, C. Desbrow, G.C. Brighty, M. Waldock, and J.P. Sumpter. 1998. Identification of estrogenic chemicals in STW effluent. 2. In vivo responses in trout and roach. Environmental Science \& Technology 32(11):1559-1565.

Sangsupan, H.A., D.E. Radcliffe, P.G. Hartel, M.B. Jenkins, W.K. Vencill, and M.L. Cabrera. 2006. Sorption and transport of $17 \beta$-estradiol and testosterone in undisturbed soil columns. Journal of Environmental Quality 35(6):2261-2272.

Schiffer, B., A. Daxenberger, K. Meyer, and H.H.D. Meyer 2001. The fate of trenbolone acetate and melengestrol acetate after application as growth promoters in cattle: Environmental studies. Environmental Health Perspectives 109(11):1145-1151.

Schwarzenberger, R., E. Mosel, R. Pamel, and E. Bamberg. 1996. Faecal steroid analysis for non-invasive monitoring of reproductive status in farm, wild and zoo animals. Animal Reproduction Science 42(1-4):515-526.

Shappell, N.W., L.O. Billey, D. Forbes, T.A. Matheny, M.E. Poach, G.B. Reddy, and P.G. Hunt. 2007
Estrogenic activity and steroid hormones in swine wastewater through a lagoon constructed wetland system. Environmental Science \& Technology 41:444-50.

Shappell, N.W., K.H. Elder, and M. West. 2010 Estrogenicity and nutrient concentration of surface waters surrounding a large confinement dairy operation using best management practices for land application of animal wastes. Environmental Science \& Technology 44:2365-2371.

Seki, M., S. Fujishima,T. Nozaka, M. Maeda, and K. Kobayashi. 2006. Comparison of response to $17 \beta$-trenbolone among three small fish species. Environmental Toxicology and Chemistry 25:2742-2752.

Shore, L. 2009. Transport of steroids in surface waters. In Hormones and Pharmaceuticals Generated by Concentrated Animal Feeding Operations, Transport in Water and Soil, eds. L.S. Shore and A. Pruden, 23-27. New York: Springer

Shore, L.S., and M. Shemesh. 2003. Naturally produced steroid hormones and their release into the environment. Pure and Applied Chemistry 75(11-12):1859-1871.

Soto, A.M., J.M. Calabro, N.V. Prechtl, A.Y. Yau, E.F. Orlando, A. Daxenberger, A.S. Kolok, L.J. Guillette Jr., B.l. Bizec, I.G. Lange, and C. Sonnenschein. 2004. Androgenic and estrogenic activity in water bodies receiving cattle feedlot effluent in eastern Nebraska, USA. Environmental Health Perspectives 112(3):346-352

Swartz, C.H., S. Reddy, M.J. Benotti, H.F. Yin, L.B. Barber, B.J. Brownawell, and R.A. Rudel. 2006. Steroid estrogens, nonylphenol ethoxylate metabolites, and other wastewater contaminants in groundwater affected by a residential septic system on Cape Cod, MA. Environmental Science \& Technology 40(16):4894-4902.

Thorpe, K.L., R.I. Cummings, T.H. Hutchinson, M. Scholze, G. Brighty, J.P. Sumpter, and C.R. Tyler. 2003. Relative potencies and combination effects of steroidal estrogens in fish. Environmental Science \& Technology 37:1142-1149.

Tyler, C.R., S. Jobling, and J.P. Sumpter. 1998. Endocrine disruption in wildlife: A critical review of the evidence. Critical Reviews in Toxicology 28(4):319-361.

UKEA (Environmental Agency of the United Kingdom). 2004. Proposed Predicted-No-Effect-Concentrations (PNECs) for natural and synthetic steroid oestrogens in surface waters. R\&D Technical Report P2-T04/1. Swindon, Wiltshire, United Kingdom: Environment Agency.

USDA (United States Department of Agriculture). 2000. Veterinary Services Info Sheet: Implant usage by US feedlots. Washington, DC: Animal and Plant Health Inspection Service. http://www.aphis.usda.gov/ animal_health/nahms/feedlot/downloads/feedlot99/ Feedlot99_is_ImplantUsage.pdf. 
USDA. 2012. Briefing rooms: Cattle. Washington, DC: USDA, Economic Research Service. http://www.ers. usda.gov/briefing/cattle/background.htm.

USEPA (United States Environmental Protection Agency). 2001. Economic analysis for the proposed revisions to the national pollutant discharge elimination system regulation and the effluent guidelines for concentrated animal feeding operations. EPA-821-R-01-001. Washington, DC: USEPA, Engineering and Analysis Division, Office of Science and Technology.

USEPA. 2004. Risk assessment evaluation for concentrated animal feeding operations. EPA/600/R-04/042. Cincinnati, OH: Office of Research and Development, National Risk Management Research Laboratory.

USEPA. 2007. Method 1698: Steroids and hormones in water, soil, sediment, and biosolids by HRGC/HRMS. EPA Document No. 821-R-08-003. Washington, DC: US Environmental Protection Agency, Office of Water.

USEPA. 2008. Endocrine disruptors in the environment: A US EPA Science To Achieve Results (STAR) Progress Review. Tampa, FL: US Environmental Protection Agency. http://www.epa.gov/ncer/publications/ workshop/edc_111608.pdf.

USEPA. 2010. Method 539: Determination of hormones in drinking water by solid phase extraction (SPE) and liquid chromatography electrospray ionization tandem mass spectrometry (LC-ESI-MS/MS). Office of Water (MLK: 140). EPA Document No. 815-B-10-001. Washington, DC: US Environmental Protection Agency.

USEPA. 2011a. Summary of the Clean Water Act. Laws and Regulations. Washington, DC: US Environmental Protection Agency. http://www.epa.gov/lawsregs/ laws/cwa.html.

USEPA. 2011b. National Pollutant Discharge Elimination System. Washington, DC: US Environmental Protection Agency. http://cfpub.epa.gov/npdes/index.cfm.

USEPA. 2011c. Impaired Waters and Total Maximum Daily Loads. Washington, DC: US Environmental Protection Agency. http://water.epa.gov/lawsregs/lawsguidance/ $\mathrm{cwa} / \mathrm{tmdl} /$.

USEPA. 2011d. National Primary Drinking Water Regulations. Drinking Water Contaminants. Washington, DC: US Environmental Protection Agency. http://water.epa.gov/drink/contaminants/ index.cfm.

USEPA. 2011e. Extramural Research. Fate and Effects of Hormones in Waste form Concentrated Animal Feeding Operations (CAFOS) (2006). Washington, DC: US Environmental Protection Agency. http:// cfpub.epa.gov/ncer_abstracts/index.cfm/fuseaction/ display.rfa/rfa_id/435.

USEPA. 2012.Water: Contaminant Candidate List. Washington, DC: US Environmental Protection Agency. http://water. epa.gov/scitech/drinkingwater/dws/ccl/ccl3.cfm.

USFDA (United States Food and Drug Administration). 2011. Steroid Hormone Implants Used for Growth in Food-Producing Animals. Washington, DC: US Food and Drug Administration, US Department of Health \& Human Services. http://www.fda.gov/AnimalVeterinary/ SafetyHealth/ProductSafetyInformation/ucm055436.htm.

Van Poucke, C., and C. Van Peteghem. 2002. Development and validation of a muli-analyte method for the detection of anabolic steroids in bovine urine with liquid chromatography-tandem mass spectrometry. Journal of Chromatography B 772:211-217.

Vos, J. G., E. Dybing, H.A. Greim, O. Ladefoged, C. Lambre, J.V. Tarazona, I. Brandt, and A.D. Vethaak. 2000. Health effects of endocrine-disrupting chemicals on wildlife, with special reference to the European situation. Critical Reviews in Toxicology 30(1):71-133.

Weyer, P., and D. Riley. 2001. Endocrine disruptors and pharmaceuticals in drinking water. Denver, CO: AWWA Research Foundation and the American Water Works Association.

WHO (World Health Organization). 2002. Global assessment of the state-of-the-science of endocrine disruptors. WHO/PCS/EDC/02.2. Geneva, Switzerland: World Health Organization/International Program on Chemical Safety. www.who.int/pcs/ emerg_site/edc/global_edc_ch5.pdf.

Young, R.B. and T. Borch. 2009. Chapter 4: Sources, presence, analysis, and fate of steroid sex hormones in freshwater ecosystems - A review. In Aquatic Ecosystem Research Trends, ed. G.H. Nairne, 103-164. New York: Nova Science Publishers.

Yang, Y., T. Borch, R.B. Young, L.D. Goodridge, and J.G. Davis. 2010. Degradation kinetics of testosterone by manure-borne bacteria: Influence of temperature, $\mathrm{pH}$, glucose amendments, and dissolved oxygen. Journal of Environmental Quality 39:1153-1160.

Yang,Y., L.P. Pereyra, R.B.Young, K.F. Reardon, and T. Borch. 2011. Testosterone- mineralizing culture enriched from swine manure: Characterization of degradation pathways and microbial community composition. Environmental Science \& Technology 45:6879-6886.

Zimbelman, R.G., J.W. Lauderdale, J.H. Sokolowski, and T.G. Schalk. 1970. Safety and pharmacologic evaluations of melengestrol acetate in cattle and other animals. A review. Journal of the American Veterinary Medical Association 157:1528-1536.

ZoBell, D., C.K. Chapman, K. Heaton, and C. Birkelo. 2000. Beef Cattle Implants. AG-509. Logan, UT: Utah State University Extension 